\title{
Assessing the Level of Performance of Sign Language Interpreters from Impaired Hearing Students' Perspectives at Public and Private Jordanian Universities
}

\author{
Feryal Abdel-Hadi Shanikat ${ }^{1}$ \\ ${ }^{1}$ The world Islamic Sciences \& Education University, Jordan \\ Correspondence: Feryal Abdel-Hadi Shanikat, The world Islamic Sciences \& Education University, Jordan. \\ E-mail: morganiteinstitute@yahoo.com
}

Received: July 10, 2014 Accepted: August 13, 2014 Online Published: November 26, 2014

doi:10.5539/ies.v7n12p53 URL: http://dx.doi.org/10.5539/ies.v7n12p53

\begin{abstract}
This study aimed at assessing the level of performance of sign language interpreters in both public and private Jordanian universities, as well as to recognize the effect of the study variables specifically gender and qualifications for acoustically disabled and interpreter, and the experience of the interpreter on the level of the performance assessment of sign language interpreters and the hearing disabled students in the capital (Amman) and Balqa' Governorates' public and private universities. The sample of the study consisted of (100) students. In order to collect the data, the researcher has built a study instrument which consists of three dimensions: a personal dimension (15), cognitive dimension (13), and professional dimension (13). Validity and reliability of the instrument were calculated, and then the instrument was applied on the study sample.

The results of the study showed that the level of assessment by the hearing disabled students for sign language interpreters who accompany them in public and private universities and institutes was high. The personal dimension came first, followed by the cognitive dimension, and finally the professional dimension. The results showed a lack of statistically significant differences on all dimensions attributed to the gender variable of the acoustically disabled. The study showed the existence of statistically significant differences in favor of females on the personal dimension attributed to the interpreter gender variable. Results also showed that there were no statistically significant differences attributed to the impact of the acoustically disabled qualifications on all dimensions except the professional one in favor of diploma, and there were no statistically significant differences attributed to the impact of the interpreter's qualifications on all dimensions except the professional one in favor of diploma, and no statistically significant differences attributed to the experience variable of the interpreter.
\end{abstract}

Keywords: language interpreters, the impaired hearing, the level of performance of sign language interpreters

\section{Introduction}

There are many definitions of audio disability due to varieties of views on the subject of hearing disabilities, the most prominent of these definitions are medical terms where it defines the disabled as the one whose hearing organic is damaged with defective organic which prevents him from using it normally in public life like any other ordinary students, this means that the defect or damage may hit the outer or middle or internal ear, this may not cover all parts of the ear, but part or parts of the ear, while academics prospective defines the Impaired hearing students as individuals who could not rely on the sense of hearing to learn the language, or taking an advantage of the various education programs provided to the hearers, or those who need to teaching methods that compensate them for the sense of hearing, but the impaired hearing is the individual who is suffering from loss of hearing ability may be able to compensate aids audio with high- intensity sound which adds him to learn in the same way like other normal students and listeners after the use of specific audio devices (Yusuf, 2006).

Hearing disability criterion varies upon depending on its classification, in this matter, there are three basic criteria in the classification of hearing disability, as mentioned below:

1) Classification depending on the age in which the disability occurred:

The age in which hearing disability occurred shall be the most important variable in determining the effects resulting from the hearing disabilities, because of its significance in specifying the child's acquisition of 
language expertise necessary in field of learning to communicate with others, and it is divided according to this standard to the following factors:

\section{A) (Pre-lingual Deafness):}

This type is called congenital, deafness that refers to cases of deafness which occurs from birth or at an earlier stage on the evolution of speech and language in children whereas the experts disagreed about the age at which separates deafness before language and deafness after linguistic as some of them believes that age is 18 months, while others think that it is 3 years is the interval age and this category usually are not able to speak, and they are the so-called deaf, dumb.

B) (Pos-lingual Deafness):

Pos-lingual Deafness refers to cases of deafness that occurs after the child has acquired the skill of speech and language and they are called the deaf only.

2) Classification according to the place of the defective organic:

This classification is based on identifying the defective organic in the auditory system, either outer or middle internal ear which caused audio obstruction, it is divided according to this standard to the following:

\section{A) (Conductive Hearing Loss):}

Conductive Hearing Loss produces problems about that affect outer or middle ear, so as to prevent the arrival of the sound wave naturally to the inner ear, it has been caused by a blockage in the external auditory canal; due to the accumulation of wax in the ear, ossifying tissues of the ear, or entering of foreign objects, or holing of the drum in the other ear.

This type of loss can be corrected medically or surgically, or using the amplifiers, and the symptoms of this type of loss of hearing is a pain in the ear, exit discharge, swelling of the outer ear, the feeling of pressure in the ear, and the degree of loss of hearing less than $70 \mathrm{~dB}$.

B) (Sensor neural Hearing Loss):

It is also called the Nerve Deafness, and result because of a damage to the inner ear or the auditory nerve, although the waves at the inner ear, but converting it to electrical discharges inspect the enclosure may not be convenient, or the imbalance in the auditory nerve is not transferred to the brain fully, and the loss of auditory sensory nervous system affects not only the ability to hear sounds, but to understand them as well; as audible beeps exposed to distortion prevents misunderstood, and often suffer the injured from the inability to hear the high sounds, and the patient in this case is classified as one who speaks loudly, and there is a weakness in the discrimination of letters and words. the most common causes of this disorder are aging, infections of the inner ear, exposure to noise, head injuries, acoustic neuronal, taking certain medications, birth defects and sensor neural hearing loss not to usually deal with medically or surgically, but this category may benefit from the earphones, but it is a low degree, the degree of hearing loss greater than $70 \mathrm{~dB}$.

\section{History of the Sign Language}

History of sign language is connected to the education of the deaf, where a lot of academics taken as a basis for education of the deaf (Al Rais, 2007). The beginning of the historical documentation to raise the deaf in addition to using the sign language in deaf education to the sixteenth century, when The Spanish monk (DeLeon) started teaching two deaf children from a wealthy family, where he was the first teacher known for the deaf in the world, and it was believed that the sign language he used was part of the way in which he used especially household signals that was used by the children then was followed by another Spaniard is Joan Bonet in 1620, who wrote a book focused on the alphabet of the fingers and how to use them to teach the deaf to speak and pronunciation, note that the alphabet fingers lead, however, and only one (Dabbas, 2007). The French (DeLeepee) first to adopt the use of alphanumeric fingers with reference not to teach speech and language, also is the first to establish a school for the deaf in the world in Paris in late 1760, as adopted has Lybithe sign language used among the deaf in Paris to teach deaf and education, and that their contributions to the delivery of information to the deaf students at ease. In the United States established the Thomas first boarding school for deaf education in America in 1817 and which has been used sign language as a way essential to the education of the deaf, where he integrates American Sign Language and French as reported by Chinese writings at the end of the second century $\mathrm{AD}$, several references to the use of the deaf sign language In the Jewish oral law for example, can a man deaf mute to address people by signs that people address him by signals. 


\subsection{Problem of the Study and Its Importance}

The interest in teaching hearing-impaired individuals in Jordan has been developed and there was a large number of impaired hearing students who complete their higher education in public and private universities, where the Supreme Council for disabled persons appointed interpreter sign language for each college student may apply to the Board relating an interpreter to accompany disabled student acoustically all lectures in the university. Due to the importance of the role played by the interpreter in the communication between the disabled translation of his thoughts and feelings, and the role he played in integrating the hearing-impaired with the community of listeners in the higher education some questions were formulated.

\subsection{Questions of the Study}

The researcher tried to answer the following questions:

1) What is the evaluation level of the performance of the sign language interpreter who accompanies the hearing-impaired in private and public universities from Hearing Impaired perspective?

2) Are there any statistically significant differences in the levels of evaluation of the performance of the sign language interpreter from the hearing impaired perspective in public and private universities due to the gender of the hearing-impaired?

3) Are there any statistically significant differences in the levels of evaluation of the performance of the sign language interpreter from the hearing impaired students perspectives in public and private universities due to the scientific qualification of the hearing impaired?

4) Are there any statistically significant differences in levels of evaluation of the performance of the sign language interpreter from the hearing impaired perspectives in public and private universities due to the gender of the interpreter?

5) Are there any statistically significant differences in levels of evaluation of the performance of the sign language interpreter from the impaired hearing perspectives in public and private universities due to scientific qualification of the interpreter?

6) Are there any statistically significant differences in levels of evaluation of the performance of the sign language interpreter from the hearing impaired perspectives in public and private universities due to the years of experience of the interpreter?

\subsection{Significance of the Study}

1) Small number of studies related to this field.

2) Increasing number of students with hearing disabilities at the public and private universities in Jordan.

3) Importance of the role of sign language interpreter in the academic life of the hearing impaired.

4) Importance of knowing the satisfaction of hearing about the role of a disabled sign language interpreter, and the extent of his ability to connect ideas to the community of the Impaired hearing students listeners at the university

5) Providing interested parties to provide sign language interpreter for the hearing impaired with information about the current level of performance of the interpreter, as well as the proposed recommendations.

\subsection{Procedural Definitions}

Hearing impaired: is a student who could not communicate with others in Jordanian universities or colleges only through sign language.

Sign language interpreter: The person who accompanying the hearing impaired student enrolled in public or private universities and colleges in Jordan, where the interpreter who delivers the message to the hearing impaired student through the sign language in addition to converting the indicative message of hearing impaired student to sound of the listeners.

\subsection{Objectives of the Study}

- Identifying the level of job performance for sign language interpreters in Jordanian public and private universities.

- Knowing the effect of gender on the hearing impaired students evaluates the level of job performance of the interpreter.

- Knowing the effect of qualification for the hearing impaired students evaluates the level of job performance of 
the interpreter.

- Knowing the effect of the gender of the interpreter in the evaluation of the level of job performance of the interpreter s from the prospective of the impaired hearing.

- Knowing the impact of the qualification of the interpreter in the evaluation of the level of job performance for interpreter s from hearing impaired perspectives.

- Knowing the effect of years of experience of the interpreter in the level of evaluation of the interpreters from hearing impaired perspectives.

\subsection{Limitations of the Study}

The study is limited to the students of public and private universities in Balqa and Amman the capital. The study is also limited to students of public and private universities severe hearing impaired students.

The study is limited to university students enrolled in the first semester 2013/2014.

\section{Review of Related Literature}

Many researchers conducted studies to investigate the significance of sign language interpreters and their role in assessing hearing impaired students, the following are some studies

Melnk (1997) conducted a study entitled "Role of Sign language interpreters in kindergarten”, at the fourth grade at schools, the study aimed to describe the roles of sign language interpreters for kindergarten deaf students through fourth grade in schools in Manitoba, where a questionnaire was distributed to a sample study consisting of (39) interpreters who their job description varies as the study conclude that there is a conflict in performance of interpreters due to the difference in the training they have received, the study indicated also that there should be standards of professional interpreters in the educational environment and it assures the need for conducting more researches in this field.

Cerney (2004) conducted a study entitled "Reciprocity interpretation of American Sign Language (The signal) through an interpreter hears another deaf", as this method of interpretation requires presence of two interpreters for sign language one hears and the other is deaf, where carrying out together to interpret a letter from English to the American sign language as well as the opposite of American Sign Language into English, and they were filming and recording a team of sign language interpreters during interpretation process for ten minutes, then analyzing the information recorded. The study found that the percentage of recorded information amounted (89\%) accuracy between the source of the message and its translation. As a discerned from the analysis that the deaf interpreter took $20 \%$ of the time of the translation team in order to produce the translated text, the study recommended that the translation is in accordance with the rules and principles agreed upon.

A study conducted by Marschark et al. (2005) entitled "Access to education beyond high school through sign language translation", and the goal of this study was to identify the effectiveness of sign language interpreters for the deaf in the classrooms, the sample consisted of 150 people, including (127) student volunteers from the Institute of Technology for the deaf rooster, among these volunteers (22) ordinary students, including (9) males and the rest were females, (105) deaf students, including 60 males and females as well as the rest (23) sign language interpreter. The researcher assigned interpreters during lectures for deaf students at the university level, then all students set for a test to see how to take advantage of the content and understanding it, where the results indicated that there were discrepancies regarding the students preferring of having interprets, and the results also pointed out that deaf students gain less information than their listening colleague, as they are weak in school readiness, quality of education and interpretation.

Bally (2007) conducted a study entitled "The History of Education of translation in American sign language." And the study aimed to analyze and authenticate the chronological history of educational interpretation depending on the information and data that have been obtained through interviews conducted with employees in organizations. The study showed the impact of social, political and legislative views of interpreters in education. The study also recommended changes and modifications in the design of systematic training for sign language interpreters.

A Study by Omari (2009) aimed to identify the required competencies for sign language interpreters from the deaf and interpreters prospective in Saudi Arabia, The study sample consisted of (531) deaf and interpreters. The researcher prepared the study instrument which consisted of 45 distributing sections divided into 3 frameworks, the study found that the personal skills competencies are more necessary for sign language interpreters for the signal, followed by professional competence and cognitive skills. The study found statistically significant differences in favor of females in the personal and professional skills, it also indicates that there are statistical 
significant differences in favor of males regarding cognitive skill dimensions.

\section{Methods and Procedures}

\subsection{The Study Community and Its Sample}

The study population consisted of all hearing impaired students enrolled in Jordanian public and private universities in the governorates of Amman the capital and Balqa during the academic year 2013/2014, estimating (150), based on the statistics of the Higher Council for Disabled Students Affairs including (100) students .

\subsection{The Study Instrument}

A scale which consisted of three dimensions: the personal dimension which consists of (15) items, and cognitive dimension which consists of (13) items, and the professional dimension which consists of (13) items, it is a four level scale: (It applies to a large extent, it applies moderately, it applies to a small degree, it does not apply)

\subsection{Validity of the Instrument}

The instrument organization validity significances are gathered through computing extracted correlation coefficients items of the scale with the total score among a pilot study excluded from the study sample and it consisted of (30) hearing impaired students, where the scale items were analyzed and the coefficient of differentiation for each item in the form of a correlation coefficient and between the total score on one hand, and between each item and between linked axis that belongs to it, and between each level of the total score on the other hand. The correlation coefficients between the items of the instrument as a whole ranging between $(-0.32$ $0.80)$, and with the framework is $(0.39-0.81)$.

\subsection{Reliability of the Instrument}

The internal reliability was computed for assuring the instrument on a sample from out aspect the exploratory study sample which consists of (30) students from the hearing impaired students by Cronbach's alpha equation, and it was appropriate for the purposes of this study

\subsection{Procedures of the Study}

The scale of the study was applied in its final shape on the hearing impaired students at the public and private universities by visiting the Supreme Council for the Affairs of students with disabilities by the researcher, where the data for the preparation of hearing impaired students enrolled in universities and interpreters working with them was gained, the researcher also contacted the Deanship of Student Affairs, in some universities, where she clarified the instrument through an interpreter specialist for students in the University of Jordan, and he met the rest of the students in Prince Ali Club for the Deaf, the researcher met deaf students from various universities and colleges in the province of the capital every Thursday at the club, they distribute the instrument and explain its clauses through an interpreter, The application process lasted one month and a half because of the different programs of the students, and the instrument was applied from 01/12/2013 to 15/01/2014.

\section{Results of the Study}

The First Question: "What is the evaluation level of the performance of sign language interpreter who accompanied the hearing impaired students in public and private universities from the hearing impaired perspective?"

To answer this question means and standard deviations of the level of evaluating the performance of sign language interpreter accompanied hearing impaired students in public and private universities from the hearing impaired, it is determined by selecting a mean as follows: 1-2 low, 2.1-3 fair, and 3.1-4 high.

Table 1. Means and standard deviations for the evaluation of the performance level of sign language interpreter hearing impaired students

\begin{tabular}{lllll}
\hline The Class & The Framework & Mean & Standard deviation & The Level \\
\hline $\mathbf{1}$ & Personal Aspect & 3.54 & 0.348 & High \\
$\mathbf{2}$ & Cognitive Aspect & 3.47 & 0.392 & High \\
$\mathbf{3}$ & Professional Aspect & 3.47 & 0.387 & High \\
& & 3.49 & .333 & High \\
\hline
\end{tabular}


Table 1 shows that the personal dimension came first with the highest mean (3.54), followedby the knowledge dimension, while the professional dimension reached a mean of (3.47), and the mean of the total score was (3.49).

Means and standard deviations of the estimates of the study sample paragraphs on each skill separately, as follows?

First: Personal Dimension

Table 2. Mean and standard deviations for the personal dimension items are arranged as follows

\begin{tabular}{|c|c|c|c|c|c|}
\hline Class & Number & Paragraphs & Mean & $\begin{array}{l}\text { Standard } \\
\text { Deviation }\end{array}$ & $\begin{array}{l}\text { The } \\
\text { level }\end{array}$ \\
\hline 1 & 1 & Looks decent & 3.74 & 0.485 & High \\
\hline 2 & 8 & Having commitment & 3.66 & 0.555 & High \\
\hline 3 & 2 & Limbs intact & 3.65 & 0.592 & High \\
\hline 4 & 5 & $\begin{array}{l}\text { Having the Secretariat in the delivery of information during } \\
\text { the translation }\end{array}$ & 3.59 & 0.668 & High \\
\hline 4 & 6 & Having the ability to adapt to new situations & 3.59 & 0.605 & High \\
\hline 6 & 3 & Having fast memory & 3.58 & 0.638 & High \\
\hline 6 & 14 & Having the ability to focus during interpretation & 3.58 & 0.535 & High \\
\hline 8 & 10 & Having interests in the interpretation profession & 3.56 & 0.671 & High \\
\hline 9 & 7 & having fast common sense & 3.54 & 0.610 & High \\
\hline 10 & 9 & Ready to accept constructive criticism & 3.52 & 0.611 & High \\
\hline 11 & 13 & Having the ability to interpret in all positions & 3.45 & 0.783 & High \\
\hline 12 & 4 & Having honesty in interpretation & 3.40 & 0.667 & High \\
\hline 13 & 12 & Having confidence in himself and his abilities & 3.33 & 0.739 & High \\
\hline \multirow[t]{2}{*}{14} & 11 & Having the ability to manage time & 3.31 & 0.761 & High \\
\hline & & Having a decent appearance & 3.53 & 0.365 & High \\
\hline
\end{tabular}

Table 2 shows that means between (3.31-3.74), as shown item (1), which states, "showing decent appearance" in the first class with total mean of (3.74) as included in the item (11), which states the following, "Having the ability time management " with a total mean (3.31) of the personal dimension as a whole is (3.53).

Second: The Cognitive Dimension

Table 3. Means and standard deviations for the cognitive dimension items

\begin{tabular}{llllll}
\hline Class & Number & Paragraphs & Mean & $\begin{array}{l}\text { Standard } \\
\text { Deviation }\end{array}$ & Level \\
\hline $\mathbf{1}$ & 4 & $\begin{array}{l}\text { Interpreting from spoken language into sign language and vice } \\
\text { versa }\end{array}$ & 3.62 & 0.663 & High \\
$\mathbf{2}$ & 9 & Understands Deaf gestures & 3.59 & 0.668 & High \\
$\mathbf{3}$ & 1 & Friendly culture and audio-wide disability & 3.55 & 0.609 & High \\
$\mathbf{4}$ & 2 & Full knowledge of sign language & 3.52 & 0.577 & High \\
$\mathbf{4}$ & 3 & Holding a bachelor's degree as a minimum & 3.52 & 0.703 & High \\
$\mathbf{6}$ & 11 & Having a sufficient experience in dealing with the deaf & 3.50 & 0.577 & High \\
7 & 8 & Having the ability to overcome the problems faced during the & 3.47 & 0.658 & High \\
\hline
\end{tabular}




\begin{tabular}{llllll}
\hline $\mathbf{8}$ & 7 & Full knowledge of sign language rules and its basis & 3.43 & .700 & High \\
$\mathbf{9}$ & 5 & Having rapid interpretation & 3.42 & 0.606 & High \\
$\mathbf{9}$ & 12 & Developing himself constantly in sign language & 3.42 & 0.768 & High \\
$\mathbf{1 1}$ & 13 & Exchange experiences and knowledge with other interpreters & 3.40 & 0.765 & High \\
$\mathbf{1 2}$ & 6 & Providing accurate interpretation for the deaf & 3.34 & 0.781 & High \\
$\mathbf{1 3}$ & 10 & Reviewing recent researches in audio disability & 3.32 & 0.737 & High \\
& & Cognitive Aspect & 3.48 & 0.367 & High \\
& & Having the ability to interpret from spoken language into sign & 3.62 & \multirow{2}{*}{ High } \\
& & & & &
\end{tabular}

Table 3 shows that means are ranging between (3.32-3.62), as indicated in item (4), which states as follows" interpreting from spoken language into sign language and vice versa," came first with total mean of (3.62), while item (10) states as follows "Reviewing recent researches in audio disability" ranging with total mean of (3.32). The mean of the cognitive aspect as a whole is (3.48).

Table 4. Means and standard deviations for the professional dimension items are arranged in descending order according to means

\begin{tabular}{|c|c|c|c|c|c|}
\hline Class & Number & Paragraphs & Mean & $\begin{array}{l}\text { Standard } \\
\text { Deviation }\end{array}$ & Level \\
\hline 1 & 13 & Has a positive relationship with the Hearing Impaired & 3.65 & 0.520 & High \\
\hline 2 & 12 & Provide feedback for the impaired hearing & 3.60 & 0.569 & High \\
\hline 3 & 6 & Having a focus on the subject of interpretation & 3.54 & 0.610 & High \\
\hline 3 & 11 & Providing the necessary assistance for the disabled when needed & 3.54 & 0.610 & High \\
\hline 5 & 10 & A flexible movements during interpretation & 3.53 & .674 & High \\
\hline 6 & 1 & Punctuality in time and attendance & 3.51 & 0.703 & High \\
\hline 7 & 7 & Having the ability to deliver all the information & 3.44 & 0.608 & High \\
\hline 8 & 2 & Having harmonically movements during interpretation & 3.42 & 0.638 & High \\
\hline 9 & 9 & $\begin{array}{l}\text { Having the ability to use other methods of communication (body } \\
\text { language, the eyes gestures) }\end{array}$ & 3.41 & 0.621 & High \\
\hline 10 & 5 & Having the ability to interpret in different positions & 3.40 & 0.725 & High \\
\hline 10 & 8 & Observance of secrets and non-disclosure in the scope of work & 3.40 & 0.765 & High \\
\hline 12 & 4 & $\begin{array}{l}\text { Taking into account the social differences among the Hearing } \\
\text { impaired students }\end{array}$ & 3.33 & .682 & High \\
\hline \multirow[t]{2}{*}{13} & 3 & $\begin{array}{l}\text { Taking into account the cultural differences among the Hearing } \\
\text { impaired students }\end{array}$ & 3.30 & 0.718 & High \\
\hline & & Professional aspect & 3.46 & 0.391 & High \\
\hline
\end{tabular}

Table 4 shows that means are ranging between (3.30-3.65), as it includes in item (13), which states, "Having a positive relationship with the hearing impaired "came first with a total mean of (3.65), while item (3) states "taking into account the cultural differences among the hearing impaired students," came last with a mean of (3.30), where the total mean of the vocational dimension as a whole is (3.46).

The Second question: Are there any statistically significant differences in the levels of evaluation of the performance of a sign language interpreter from the hearing impaired students in public and private universities attributable to the Hearing impaired students' gender?

To answer this question means and standard deviations were computed for the levels of evaluation of the performance of a sign language interpreter from the Hearing Impaired Students perspective in public and private 
universities based on Hearing impaired Students' gender, where the statistical differences means test " $T$ " test was used as illustrated in the table below.

Table 5. Means, standard deviations and "T" test for effectiveness of a sign language interpreter from the hearing impaired Students perspectives in public and private universities based on hearing impaired Students' gender

\begin{tabular}{llllllll}
\hline & $\begin{array}{l}\text { Hearing Impaired } \\
\text { Students Gender }\end{array}$ & Number & Mean & $\begin{array}{l}\text { Standard } \\
\text { Deviation }\end{array}$ & $\begin{array}{l}\text { “T” } \\
\text { Value }\end{array}$ & $\begin{array}{l}\text { Degrees } \\
\text { Freedom }\end{array}$ & $\begin{array}{l}\text { Statistical } \\
\text { Significance }\end{array}$ \\
\hline $\begin{array}{l}\text { Personal } \\
\text { Aspect }\end{array}$ & Male & 63 & 3.52 & 0.362 & -0.445 & 98 & 0.657 \\
Cegnitive & Male & 37 & 3.56 & 0.326 & & & 0.368 \\
Aspect & Female & 63 & 3.44 & 0.332 & -0.905 & 98 & \\
Professional & Male & 37 & 3.52 & 0.480 & & & 0.404 \\
Aspect & Female & 63 & 3.44 & 0.389 & -0.838 & 98 & .410 \\
Total Score & Male & 37 & 3.51 & 0.387 & & & \\
& Female & 63 & 3.47 & 0.319 & -0.827 & 98 & \\
\end{tabular}

Table 5 indicates a lack of statistical significant differences equals to $(\alpha=0.05)$ due to the effectiveness of hearing impaired students' gender

The Third Question: Are there any statistically significant differences in the levels of evaluation of the performance of a sign language interpreter from the hearing impaired students' perspectives in public and private universities attributable to interpreter gender?

To answer this question means and standard deviations were computed for the levels of evaluation of the performance of a sign language interpreter from the Hearing impaired Students perspectives in public and private universities based on interpreter's gender, where the statistical differences means test " $T$ " test was used as illustrated in the table below.

Table 6. Means, standard deviations and " $\mathrm{T}$ " test for effectiveness of a sign language interpreter from the hearing impaired Students perspectives in public and private universities based on interpreter's gender

\begin{tabular}{|c|c|c|c|c|c|c|c|}
\hline & $\begin{array}{l}\text { Interpreter } \\
\text { Gender }\end{array}$ & Number & Mean & $\begin{array}{l}\text { Standard } \\
\text { Deviation }\end{array}$ & $\begin{array}{l}\text { "T" } \\
\text { Value }\end{array}$ & $\begin{array}{l}\text { Degrees of } \\
\text { Freedom }\end{array}$ & $\begin{array}{l}\text { Statistical } \\
\text { Significance }\end{array}$ \\
\hline \multirow{2}{*}{$\begin{array}{l}\text { Personal } \\
\text { Aspect }\end{array}$} & Male & 53 & 3.47 & 0.373 & \multirow[t]{2}{*}{-1.983} & \multirow[t]{2}{*}{98} & \multirow[t]{2}{*}{.050} \\
\hline & Female & 47 & 3.61 & .304 & & & \\
\hline \multirow{2}{*}{$\begin{array}{l}\text { Cognitive } \\
\text { Aspect }\end{array}$} & Male & 53 & 3.47 & 0.349 & \multirow[t]{2}{*}{0.145} & \multirow[t]{2}{*}{98} & \multirow[t]{2}{*}{0.885} \\
\hline & Female & 47 & 3.46 & 0.440 & & & \\
\hline \multirow{2}{*}{$\begin{array}{l}\text { Professional } \\
\text { Aspect }\end{array}$} & Male & 53 & 3.47 & 0.356 & \multirow[t]{2}{*}{.170} & \multirow[t]{2}{*}{98} & \multirow[t]{2}{*}{0.865} \\
\hline & Female & 47 & 3.46 & 0.424 & & & \\
\hline \multirow{2}{*}{ Total Score } & Male & 53 & 3.47 & 0.330 & \multirow[t]{2}{*}{-0.593} & \multirow[t]{2}{*}{98} & \multirow[t]{2}{*}{0.555} \\
\hline & Female & 47 & 3.51 & .338 & & & \\
\hline
\end{tabular}

Table 6 indicates lack of statistical significant differences $(\alpha=0.05)$ due to the effectiveness of interpreter gender in all aspects except for the personal one, the differences were in favor of females.

The Fourth Question: Are there any statistically significant differences in the levels of evaluation of performance of a sign language interpreter from the hearing impaired Students perspectives in public and private universities attributable to their academic qualification?

To answer this question means and standard deviations were computed for the levels of evaluation of the performance of a sign language interpreter from the Hearing Impaired Students' perspective in public and private 
universities based on their academic qualification, where the statistical differences means test "T" test was used as illustrated in the table below.

Table 7. Means, standard deviations and "T" test for effectiveness of a sign language interpreter from the hearing impaired Students' perspective in public and private universities based on their academic qualification

\begin{tabular}{lllll}
\hline & Hearing Impaired Students' Academic Qualification & Number & Mean & Standard Deviation \\
\hline \multirow{5}{*}{ Personal Aspect } & Diploma & 16 & 3.51 & 0.469 \\
& Bachelor & 75 & 3.57 & 0.316 \\
& Graduate & 9 & 3.29 & 0.281 \\
& Total & 100 & 3.54 & 0.348 \\
& Diploma & 16 & 3.59 & .308 \\
& Bachelor & 75 & 3.46 & 0.421 \\
& Graduate & 9 & 3.37 & .220 \\
& Total & 100 & 3.47 & 0.392 \\
& Diploma & 16 & 3.63 & 0.216 \\
& Bachelor & 75 & 3.46 & 0.416 \\
& Graduate & 9 & 3.21 & 0.217 \\
& Total & 100 & 3.47 & 0.387 \\
& Diploma & 16 & 3.57 & .300 \\
& Bachelor & 75 & 3.50 & .350 \\
& Graduate & 9 & 3.29 & 0.085 \\
\hline
\end{tabular}

Table 7 shows apparent variation in the means and standard deviations for the levels of evaluation of the performance of a sign language interpreter from the Hearing Impaired Students' perspectives in public and private universities due to different classes of scientific qualification variable for hearing impaired, for clarifying statistical differences analysis of variance (ANOVA) between means were used according to the Table 8 .

Table 8. Analysis of variance (ANOVA) of effectiveness for academic qualification for Hearing Impaired Students on the levels of performance evaluation of a sign language interpreter from the hearing impaired students' perspectives in public and private universities

\begin{tabular}{|c|c|c|c|c|c|c|}
\hline & $\begin{array}{l}\text { The } \\
\text { Sources }\end{array}$ & $\begin{array}{l}\text { Number of } \\
\text { Squares }\end{array}$ & $\begin{array}{l}\text { Degrees of } \\
\text { Freedom }\end{array}$ & $\begin{array}{l}\text { Means of } \\
\text { Squares }\end{array}$ & $\begin{array}{l}\text { (T) } \\
\text { Value }\end{array}$ & $\begin{array}{l}\text { Statistical } \\
\text { Significance }\end{array}$ \\
\hline \multirow{3}{*}{ Personal Aspect } & $\begin{array}{l}\text { Among } \\
\text { groups }\end{array}$ & 0.670 & 2 & 0.335 & 2.873 & 0.061 \\
\hline & $\begin{array}{l}\text { Within } \\
\text { groups; }\end{array}$ & 11.305 & 97 & 0.117 & & \\
\hline & Total & 11.974 & 99 & & & \\
\hline \multirow{3}{*}{$\begin{array}{l}\text { Cognitive } \\
\text { Aspect }\end{array}$} & $\begin{array}{l}\text { Among } \\
\text { groups }\end{array}$ & 0.326 & 2 & 0.163 & 1.060 & .350 \\
\hline & $\begin{array}{l}\text { Within } \\
\text { groups; }\end{array}$ & 14.899 & 97 & 0.154 & & \\
\hline & Total & 15.225 & 99 & & & \\
\hline \multirow{2}{*}{$\begin{array}{l}\text { Professional } \\
\text { Aspect }\end{array}$} & $\begin{array}{l}\text { Among } \\
\text { groups }\end{array}$ & 0.978 & 2 & 0.489 & 3.418 & 0.037 \\
\hline & Within & 13.877 & 97 & 0.143 & & \\
\hline
\end{tabular}




\begin{tabular}{|c|c|c|c|c|c|c|}
\hline & groups; & & & & \multirow{5}{*}{2.206} & \multirow{5}{*}{0.116} \\
\hline \multirow{4}{*}{ Total Score } & Total & 14.855 & 99 & & & \\
\hline & $\begin{array}{l}\text { Among } \\
\text { groups }\end{array}$ & 0.477 & 2 & 0.239 & & \\
\hline & $\begin{array}{l}\text { Within } \\
\text { groups; }\end{array}$ & 10.486 & 97 & \multirow[t]{2}{*}{0.108} & & \\
\hline & The Total & 10.963 & 99 & & & \\
\hline
\end{tabular}

Table 8 shows lack of statistical significant differences at level of $(\alpha=0.05)$ due to effectiveness of the academic qualification for Hearing Impaired Students in all aspects except for the professional one, where double statistical significant differences between means were used in oral and dimensional comparisons as shown in the Table 9 below.

Table 9. Dimensional comparison by oral method effectiveness of the academic qualification for hearing impaired students on the professional aspect

\begin{tabular}{llllll}
\hline & & Mean & Diploma & Bachelor & Graduate \\
\hline \multirow{4}{*}{ Professional Aspect } & Diploma & 3.63 & & & \\
& Bachelor & 3.46 & 0.16 & & \\
& Graduate & 3.21 & $0.41^{*}$ & 0.25 & \\
\hline
\end{tabular}

* Function at the level of significance $(\alpha=0.05)$.

Table 9 shows that there is a statistical significant difference $(\alpha=0.05)$ between the Diploma and the Graduate, where the differences were in favor of a diploma, in the professional aspect.

Fifth question: Are there any statistically significant differences in the levels of evaluation of the performance of a sign language interpreter from the hearing impaired students' perspectives in public and private universities attributable to interpreter's academic qualification? To answer this question means and standard deviations were computed for evaluation of performance levels of a sign language interpreter from the hearing impaired students' perspectives in public and private universities for interpreter academic qualification as illustrated in the following table.

Table 10. Means and standard deviations for evaluation of the performance levels of a sign language interpreter from the hearing impaired students' perspectives in public and private universities for interpreter academic qualification

\begin{tabular}{|c|c|c|c|c|}
\hline & Academic Qualification for Interpreter & Number & Mean & Standard Deviation \\
\hline \multirow{4}{*}{ Personal Aspect } & Diploma & 33 & 3.56 & 0.444 \\
\hline & Bachelor & 59 & 3.51 & 0.306 \\
\hline & Graduate & 8 & 3.61 & 0.138 \\
\hline & Total & 100 & 3.54 & 0.348 \\
\hline \multirow{4}{*}{ Cognitive Aspect } & Diploma & 33 & 3.50 & 0.443 \\
\hline & Bachelor & 59 & 3.42 & 0.376 \\
\hline & Graduate & 8 & 3.69 & 0.154 \\
\hline & Total & 100 & 3.47 & 0.392 \\
\hline \multirow{3}{*}{ Professional Aspect } & Diploma & 33 & 3.59 & 0.298 \\
\hline & Bachelor & 59 & 3.37 & 0.426 \\
\hline & Graduate & 8 & 3.65 & .170 \\
\hline
\end{tabular}




\begin{tabular}{lllll}
\hline \multirow{3}{*}{ Total Score } & Total & 100 & 3.47 & 0.387 \\
& Diploma & 33 & 3.55 & 0.356 \\
& Bachelor & 59 & 3.44 & 0.332 \\
& Graduate & 8 & 3.65 & 0.073 \\
& Total & 100 & 3.49 & 0.333 \\
\hline
\end{tabular}

Table 10 shows apparent variation in means and standard deviations for the levels of evaluation of the performance of a sign language interpreter from the hearing impaired students' perspectives in public and private universities due to different categories of academic qualification variable of an interpreter for clarifying statistical differences analysis of variance (ANOVA) between means were used according to Table 11.

Table 11. Analysis of variance (ANOVA) of effectiveness of academic qualification of the interpreter to evaluate the performance levels of a sign language interpretation from the hearing impaired students' perspectives in public and private universities

\begin{tabular}{|c|c|c|c|c|c|c|}
\hline & $\begin{array}{l}\text { The } \\
\text { Sources }\end{array}$ & $\begin{array}{l}\text { Number of } \\
\text { Squares }\end{array}$ & $\begin{array}{l}\text { Degrees of } \\
\text { Freedom }\end{array}$ & $\begin{array}{l}\text { Means of } \\
\text { Squares }\end{array}$ & $\begin{array}{l}\text { T) } \\
\text { Value }\end{array}$ & $\begin{array}{l}\text { Statistical } \\
\text { Significance }\end{array}$ \\
\hline \multirow{3}{*}{ Personal Aspect } & $\begin{array}{l}\text { Among } \\
\text { groups }\end{array}$ & 0.087 & 2 & 0.044 & .357 & 0.701 \\
\hline & $\begin{array}{l}\text { Within } \\
\text { groups; }\end{array}$ & 11.887 & 97 & 0.123 & & \\
\hline & Total & 11.974 & 99 & & & \\
\hline \multirow{3}{*}{$\begin{array}{l}\text { Cognitive } \\
\text { Aspect }\end{array}$} & $\begin{array}{l}\text { Among } \\
\text { groups }\end{array}$ & 0.556 & 2 & 0.278 & 1.839 & 0.164 \\
\hline & $\begin{array}{l}\text { Within } \\
\text { groups; }\end{array}$ & 14.669 & 97 & 0.151 & & \\
\hline & Total & 15.225 & 99 & & & \\
\hline \multirow{3}{*}{$\begin{array}{l}\text { Professional } \\
\text { Aspect }\end{array}$} & $\begin{array}{l}\text { Among } \\
\text { groups }\end{array}$ & 1.299 & 2 & 0.650 & 4.648 & .012 \\
\hline & $\begin{array}{l}\text { Within } \\
\text { groups; }\end{array}$ & 13.556 & 97 & .140 & & \\
\hline & Total & 14.855 & 99 & & & \\
\hline \multirow{3}{*}{ Total Score } & $\begin{array}{l}\text { Among } \\
\text { groups }\end{array}$ & 0.479 & 2 & 0.240 & 2.216 & 0.115 \\
\hline & $\begin{array}{l}\text { Within } \\
\text { groups }\end{array}$ & 10.484 & 97 & 0.108 & & \\
\hline & Total & 10.963 & 99 & & & \\
\hline
\end{tabular}

Table 11 indicates lack of statistical significant differences at level of $(\alpha=0.05)$ due to the effectiveness of the academic qualification of the interpreter in all aspects except for the professional aspect where double statistical significant differences between means were used in oral and dimensional comparisons as shown in Table 12. 
Table 12. Dimensional oral method comparisons for effectiveness of the interpreter academic qualification on the professional aspect

\begin{tabular}{lccccc}
\hline & & Mean & Diploma & Bachelor & Graduate \\
\hline \multirow{3}{*}{ Professional Aspect } & Diploma & 3.59 & & & \\
& Bachelor & 3.37 & $0.22 *$ & & \\
& Graduate & 3.65 & .06 & 0.25 & 0.28 \\
\hline
\end{tabular}

* Function at the level of significance $(\alpha=0.05)$.

Table 12 indicates a statistical significant difference at the level of $(\alpha=0.05)$ between the diploma and the bachelor with the differences in favor of a diploma in the professional aspect.

The sixth question: Are there any statistically significant differences in the levels of evaluation of the performance of a sign language interpreter from the hearing impaired students' perspectives in public and private universities due to the years of experience of the interpreter?

To answer this question means and standard deviations for the evaluation of the performance levels of a sign language interpreter from the hearing impaired students' perspectives in public and private universities by years of experience of the interpreter as shown in the table below.

Table 13. Means and standard deviations for evaluation of the performance levels of a sign language interpreter from the hearing impaired students' perspectives in public and private universities by years of experience of the interpreter

\begin{tabular}{lllll}
\hline & Interpreter Years of Experience & Number & Mean & Standard Deviation \\
\hline \multirow{4}{*}{ Personal Aspect } & Two years or less & 13 & 3.47 & 0.480 \\
& More than two years to 5 years & 48 & 3.57 & 0.301 \\
& More than 5 years & 39 & 3.52 & .357 \\
& Total & 100 & 3.54 & 0.348 \\
& Two years or less & 13 & 3.43 & 0.182 \\
& More than two years to 5 years & 48 & 3.54 & 0.379 \\
Cognitive Aspect & More than 5 years & 39 & 3.39 & 0.446 \\
& Total & 100 & 3.47 & 0.392 \\
& Two years or less & 13 & 3.55 & .177 \\
& More than two years to 5 years & 48 & 3.45 & 0.388 \\
& More than 5 years & 39 & 3.46 & 0.438 \\
& Total & 100 & 3.47 & 0.387 \\
& Two years or less & 13 & 3.48 & 0.233 \\
& More than two years to 5 years & 48 & 3.52 & 0.312 \\
& More than 5 years & 39 & 3.46 & 0.385 \\
& Total & 100 & 3.49 & 0.333 \\
\hline
\end{tabular}

Table 13 shows apparent variation in the means and standard deviations for the levels of evaluation of performance of a sign language interpreter from the hearing impaired students' perspectives in public and private universities due to different classes of years of experience of the interpreter variable, for clarifying statistical differences analysis of variance (ANOVA) between means were used according to the Table 14. 
Table 14. Analysis of variance (ANOVA) effectiveness of years of experience of the interpreter to evaluate the performance levels of a sign language interpreter from the hearing impaired students' perspectives in public and private universities

\begin{tabular}{|c|c|c|c|c|c|c|c|c|c|}
\hline & $\begin{array}{l}\text { The } \\
\text { Sources }\end{array}$ & $\begin{array}{l}\text { Number } \\
\text { Squares }\end{array}$ & of & $\begin{array}{l}\text { Degrees } \\
\text { Freedom }\end{array}$ & of & $\begin{array}{l}\text { Means } \\
\text { Squares }\end{array}$ & of & $\begin{array}{l}\text { (T) } \\
\text { Value }\end{array}$ & $\begin{array}{l}\text { Statistical } \\
\text { Significance }\end{array}$ \\
\hline \multirow{3}{*}{ Personal Aspect } & $\begin{array}{l}\text { Among } \\
\text { groups }\end{array}$ & 0.118 & & 2 & & 0.059 & & 0.482 & 0.619 \\
\hline & $\begin{array}{l}\text { Within } \\
\text { groups; }\end{array}$ & 11.857 & & 97 & & 0.122 & & & \\
\hline & Total & 11.974 & & 99 & & & & & \\
\hline \multirow{3}{*}{$\begin{array}{l}\text { Cognitive } \\
\text { Aspect }\end{array}$} & $\begin{array}{l}\text { Among } \\
\text { groups }\end{array}$ & 0.517 & & 2 & & 0.258 & & 1.705 & 0.187 \\
\hline & $\begin{array}{l}\text { Within } \\
\text { groups; }\end{array}$ & 14.708 & & 97 & & 0.152 & & & \\
\hline & Total & 15.225 & & 99 & & & & & \\
\hline \multirow{3}{*}{$\begin{array}{l}\text { Professional } \\
\text { Aspect }\end{array}$} & $\begin{array}{l}\text { Among } \\
\text { groups }\end{array}$ & 0.104 & & 2 & & 0.052 & & 0.342 & 0.711 \\
\hline & $\begin{array}{l}\text { Within } \\
\text { groups; }\end{array}$ & 14.751 & & 97 & & 0.152 & & & \\
\hline & Total & 14.855 & & 99 & & & & & \\
\hline \multirow{3}{*}{ Total Score } & $\begin{array}{l}\text { Among } \\
\text { groups }\end{array}$ & 0.096 & & 2 & & 0.048 & & 0.430 & 0.652 \\
\hline & $\begin{array}{l}\text { Within } \\
\text { groups }\end{array}$ & 10,866 & & 97 & & 0.112 & & & \\
\hline & Total & 10.963 & & 99 & & & & & \\
\hline
\end{tabular}

Table 14 indicates lack of statistical significant differences at level of $(\alpha=0.05)$ due to years of experience of the interpreter in all aspects as well as in the total score.

\subsection{Discussion of the Findings}

The First Question: "What is the evaluation level of the performance of sign language interpreter who accompanied the hearing impaired students in public and private universities from the hearing impaired perspective?"

The high level assessment of hearing impaired interpreters at the university level, the personal aspect came first, while the cognitive and professional aspects came after as these conclusions were in consistent with the study results by Alomeri (2009) in, which aimed to identify the required competencies for sign language interpreters as the personal skills were in the first position from the perspective of the deaf and sign language interpreters in Kingdom of Saudi Arabia, as included in item (13) which states as follows: "Having a friendly positive relationship with the impaired hearing students "came first place in the personal aspect, as a sign language in Jordanian universities accompanying impaired hearing students to lectures at various colleges as well as at the university facilities were the interpreters sometimes spend long time with them at the university as they concentrate on emphasis of the personal aspect to the interpreter with all their properties based on the success of the process for integrating the hearing impaired students at the university, this conclusion contradicts with a study conducted by (Melnk, 1999) which concluded a need for a professional standards for the interpreter profession.

Second question: Are there any statistically significant differences in the levels of evaluation of the performance of a sign language interpreter from the hearing impaired students in public and private universities attributable to the Hearing impaired students ' gender?

The answer for this question indicates a lack of statistical significant differences due to the gender variable on all dimensions, where this result is in consistent with the study conducted by (Boll, 2007), entitled "History of 
interpretation education by American Sign Language where the study concluded presence of positive trends in general direction of sign language interpreters, where the hearing impaired students who enrolled in the university education stage have the same needs, as a sign language interpreter is trained to meet those needs for both genders, therefore, there is no statistical significant differences attributed to gender in addition that each hearing impaired student is accompanied by an interpreter from the same gender.

The Third Question: Are there any statistically significant differences in the levels of evaluation of the performance of a sign language interpreter from the hearing impaired students' perspectives in public and private universities attributable to interpreter gender?

Results indicated presence of statistical significant differences in favor of females on the personal aspect, this result is consistent with the result of Al Omari (2009) study, which confirms that there is statistical significant differences in favor of females on the personal aspect where this result is considered a logical one as females are more committed and have interest in the personal aspect than males, besides they are more successful in establishing personal relationships with hearing impaired students than males as they are more tolerant to the superiority of the female to male interpreters in this dimension.

The Fourth Question: Are there any statistically significant differences in the levels of evaluation of performance of a sign language interpreter from the hearing impaired Students perspectives in public and private universities attributable to their academic qualification?

The result indicates lack of statistical significant differences due to effectiveness of the academic qualification for impaired hearing students in all aspects except for the professional aspect attributable to diploma, where this conclusion is in consistent with the study of (Melnk, 1997) entitled "Role of sign language interpreters in kindergartens, until the fourth grade in the educational centers", the study also confirmed a need for a professional standards for the interpretation profession, where sign language compared with the spoken Arabic language is weak with its concepts which require implementing only indicative sign vocabulary to keep up with the progress, as the diploma students are more in need of a professional interpreter in the professional aspect, and because the student diploma, compared with graduate and undergraduate ones have less experience as required in the study after high school, therefore, there is a need for excellent interpreter in the professional field.

Fifth question: Are there any statistically significant differences in the levels of evaluation of the performance of a sign language interpreter from the hearing impaired students' perspectives in public and private universities attributable to interpreter's academic qualification?

The results indicates lack of statistical significant differences due to the effectiveness of the interpreter academic qualification in all aspects except for the professional aspect differences attributable to the diploma where this finding is consistent with the result with the study conducted by (Marschark et al., 2005) entitled "Access to education beyond high school through sign language interpretation" as the goal of this study is to identify the effectiveness of sign language interpreters for the deaf in the classroom, the study concluded that there were discrepancies regarding the importance of the students prefer the interpretation, and pointed out that deaf students gain less information from their fellow listeners, as they are weak in their school homework, the quality of education and the quality of interpretation as well.

The sixth question: Are there any statistically significant differences in the levels of evaluation of the performance of a sign language interpreter from the hearing impaired students' perspectives in public and private universities due to the years of experience of the interpreter?

The results show lack of statistical significant differences due to the years of experience of the interpreter in all aspects and in the total score. These conclusions are in consistent with the study conducted by (Cerney, 2004) entitled "Reciprocity Interpretation of American Sign Language (signal) through a hearing interpreter with another deaf", where this interpretation method requires two interpreters for the signal language one of them is deaf while the other one is listener. The study concluded that the interpretation process took $20 \%$ of the time, the study recommended a need for the interpretation has to be in accordance with certain rules and criteria as interpretation experience plays a minor role in the evaluation process, where the idea of providing each impaired hearing student with sign language interpreter as this idea is somewhat modern in which the interpreter are exposed to modern concepts to be interpreted for hearing impaired student, but what is important compliance with the rules and standards of the interpretation.

\subsection{Recommendations}

- A need for conducting further studies regarding the deaf skills in using sign languages.

- It is required to conduct further studies on the adequacy of the sign language interpreters from the prospective 
of the deaf themselves.

- It is recommended to hold training for listeners about sign language, in order to integrate the deaf in the world of listeners.

- Doing the best efforts for preparing a unified signal language dictionary.

- Conducting training for the deaf about the use of scientific sign language.

\section{References}

Al Omeri. (2009). Competencies necessary for sign language interpreters from the perspective of the deaf and interpreters in the Kingdom of Saudi Arabia (Master thesis, King Saud University).

Al Rais, T. (2007). Sign language and visual media, realistic vision of a working paper submitted to the seventh meeting of the Gulf Disability Society. Manama, Bahrain.

Bally, C. (2007). ProQuest Dissertation And Theses Section 1351, Part 0337175 pages (PhD. dissertation, United States Minnesota Copella University).

Cerney, B. E. (2004). Relayed Interpretation from English to American Sign Language (PhD. dissertation, Ohio union Institute and University, United States). Proqest dissertation And Theses Section 1414, Part 0290 Pages.

Dabbas, N. (2007). Deaf Education: Arab and international efforts, an excellent enterprise for printing and binding, Riyadh.

Marschark, M., Sapere, C., \& Seewagen, R. (2005). Access to Postsecondary through Sing Language Interpreting. Journal of Deaf.

Melnk, K. (1997). The Role of Sign language Interpreters in Kindergarten to senior education settings (Dissertation, Maniroba University of Canada).

Yusuf, T. (2006). Bilingual education for deaf students (Bilingual and bi-cultural, V1, Riyadh, King Fahd National Library).

\section{Appendix}

The Study Instrument

\begin{tabular}{|c|c|c|c|c|c|}
\hline Series & Paragraphs & $\begin{array}{l}\text { Applicable } \\
\text { Significantly }\end{array}$ & $\begin{array}{l}\text { Applicable } \\
\text { Moderately }\end{array}$ & $\begin{array}{l}\text { Applicable } \\
\text { with Low } \\
\text { Degree }\end{array}$ & Not Applicable \\
\hline \multicolumn{6}{|c|}{ First: $\quad$ Personal Aspect } \\
\hline 1 & Decent Appearance & & & & \\
\hline 2 & Healthy Limbs & & & & \\
\hline 3 & Having fast memory & & & & \\
\hline 4 & $\begin{array}{l}\text { Having honesty in } \\
\text { Interpretation }\end{array}$ & & & & \\
\hline 5 & $\begin{array}{l}\text { Maintaining } \\
\text { confidentiality delivery of } \\
\text { information during the } \\
\text { Interpretation }\end{array}$ & & & & \\
\hline 6 & $\begin{array}{l}\text { Having the ability to adapt } \\
\text { to new situations }\end{array}$ & & & & \\
\hline 7 & $\begin{array}{l}\text { Having rapid common } \\
\text { sense }\end{array}$ & & & & \\
\hline 8 & $\begin{array}{l}\text { Having commitment and } \\
\text { Punctuality }\end{array}$ & & & & \\
\hline 9 & $\begin{array}{l}\text { Accepting } \\
\text { criticism }\end{array}$ & & & & \\
\hline
\end{tabular}




\begin{tabular}{|c|c|c|c|c|c|}
\hline 10 & $\begin{array}{l}\text { Having interest in } \\
\text { Interpretation Profession }\end{array}$ & & & & \\
\hline 11 & $\begin{array}{l}\text { Having the ability to } \\
\text { utilize time properly }\end{array}$ & & & & \\
\hline 12 & $\begin{array}{l}\text { Having self- confidence in } \\
\text { his capabilities }\end{array}$ & & & & \\
\hline 13 & $\begin{array}{l}\text { Having the ability to } \\
\text { interpret under pressure }\end{array}$ & & & & \\
\hline 14 & $\begin{array}{l}\text { Having the ability to } \\
\text { concentrate during the } \\
\text { Interpretation }\end{array}$ & & & & \\
\hline 15 & $\begin{array}{ll}\text { Unashamed } & \text { during } \\
\text { Interpretation } & \end{array}$ & & & & \\
\hline \multicolumn{6}{|c|}{ Second: $\quad$ Cognitive Aspect } \\
\hline 1 & $\begin{array}{l}\text { Having a wide range of } \\
\text { disability culture and audio }\end{array}$ & & & & \\
\hline 2 & $\begin{array}{l}\text { Having full knowledge in } \\
\text { sign language }\end{array}$ & & & & \\
\hline 3 & $\begin{array}{l}\text { holding a } \\
\text { degree as a } \\
\text { qualification }\end{array}$ & & & & \\
\hline 4 & $\begin{array}{lcr}\text { Ability from } & \text { spoken } \\
\text { language } & \text { into } & \text { sign } \\
\text { language } & \text { and vice versa }\end{array}$ & & & & \\
\hline 5 & Ability to interpret rapidly & & & & \\
\hline 6 & $\begin{array}{ll}\text { Having } & \text { accurate } \\
\text { interpretation } & \end{array}$ & & & & \\
\hline 7 & $\begin{array}{l}\text { Having full knowledge of } \\
\text { rules of sign language and } \\
\text { its basis }\end{array}$ & & & & \\
\hline 8 & $\begin{array}{l}\text { Ability to overcome the } \\
\text { problems encountered } \\
\text { during the interpretation }\end{array}$ & & & & \\
\hline 9 & $\begin{array}{ll}\text { Understanding } & \text { Deaf } \\
\text { gestures } & \end{array}$ & & & & \\
\hline 10 & $\begin{array}{l}\text { Reviewing recent research } \\
\text { disability }\end{array}$ & & & & \\
\hline 11 & $\begin{array}{l}\text { Having sufficient } \\
\text { experience in dealing with } \\
\text { the deaf }\end{array}$ & & & & \\
\hline 12 & $\begin{array}{l}\text { Developing himself } \\
\text { constantly in sign language }\end{array}$ & & & & \\
\hline 13 & \begin{tabular}{l}
\multicolumn{4}{l}{ Exchange experiences and } \\
knowledge with other \\
interpreters in \\
language
\end{tabular} & & & & \\
\hline Series & Paragraphs & $\begin{array}{l}\text { Applicable } \\
\text { Significantly }\end{array}$ & $\begin{array}{l}\text { Applicable } \\
\text { Moderately }\end{array}$ & \begin{tabular}{l}
\multicolumn{3}{l}{ Applicable } \\
with Low
\end{tabular} & Not Applicable \\
\hline
\end{tabular}




\begin{tabular}{|c|c|c|c|}
\hline & & Degree & \\
\hline \multicolumn{4}{|c|}{ Third: $\quad$ Professional Aspect } \\
\hline 1 & $\begin{array}{l}\text { Commitment in time and } \\
\text { attendance }\end{array}$ & & \\
\hline 2 & $\begin{array}{lr}\text { Having } & \text { harmonically } \\
\text { movements } & \text { during } \\
\text { interpretation } & \end{array}$ & & \\
\hline 3 & $\begin{array}{l}\text { Taking into account the } \\
\text { cultural } \\
\text { between the ifferences } \\
\text { hearing }\end{array}$ & & \\
\hline 4 & $\begin{array}{l}\text { Taking into account the } \\
\text { social distinctions between } \\
\text { the impaired hearing } \\
\text { students }\end{array}$ & & \\
\hline 5 & $\begin{array}{l}\text { Having the ability to } \\
\text { interpret in different } \\
\text { positions }\end{array}$ & & \\
\hline 6 & $\begin{array}{l}\text { Having the ability to focus } \\
\text { on the subject of } \\
\text { interpretation }\end{array}$ & & \\
\hline 7 & $\begin{array}{l}\text { Having the ability to } \\
\text { deliver all the information }\end{array}$ & & \\
\hline 8 & $\begin{array}{l}\text { Maintaining } \\
\text { confidentiality and } \\
\text { non-disclosure in scope of } \\
\text { work }\end{array}$ & & \\
\hline 9 & $\begin{array}{l}\begin{array}{l}\text { Having the ability } \\
\text { other methods }\end{array} \\
\text { of of } \\
\begin{array}{l}\text { communication } \\
\text { language, the } \\
\text { gestures) }\end{array}\end{array}$ & & \\
\hline 10 & $\begin{array}{l}\text { A flexible movements } \\
\text { during interpretation }\end{array}$ & & \\
\hline 11 & $\begin{array}{l}\text { Providing the necessary } \\
\text { assistance for the disabled } \\
\text { with impaired hearing } \\
\text { when needed }\end{array}$ & & \\
\hline 12 & $\begin{array}{l}\text { Providing feedback for the } \\
\text { impaired hearing }\end{array}$ & & \\
\hline 13 & $\begin{array}{l}\text { Having a positive } \\
\text { relationship with the } \\
\text { impaired hearing }\end{array}$ & & \\
\hline
\end{tabular}

\section{Copyrights}

Copyright for this article is retained by the author(s), with first publication rights granted to the journal.

This is an open-access article distributed under the terms and conditions of the Creative Commons Attribution license (http://creativecommons.org/licenses/by/3.0/). 